\title{
Interleukin-6, Tumor Necrosis Factor a and Metabolic Disorders in Youth
}

\author{
Konstantinos Kitsios ${ }^{\mathrm{a}, \mathrm{e}}$, Maria Papadopoulou ${ }^{\mathrm{b}}$, Konstantina Kosta ${ }^{\mathrm{b}}$, Nikolaos Kadoglou, \\ Dimitrios Chatzidimitriou ${ }^{\mathrm{d}}$, Fani Chatzopoulou ${ }^{\mathrm{d}}$, Maria Papagianni ${ }^{\mathrm{b}}$, \\ Kiriaki Tsiroukidou $^{\text {b }}$ Nikolaos Malisiovas ${ }^{\mathrm{d}}$
}

\begin{abstract}
Background: To compare Interleukin-6 (IL-6) and Tumor Necrosis Factor a $(\mathrm{TNF} \alpha)$ levels in obese and overweight youth to their normal weight counterparts. Furthermore, we compared IL- 6 and $\mathrm{TNF} \alpha$ levels in obese and overweight individuals with and without additional metabolic disorders such as Metabolic Syndrome (MS), Non Alcoholic Fatty Liver Disease (NAFLD) and prediabetes.
\end{abstract}

Methods: All 54 consecutive obese children and adolescents with Body Mass Index $(\mathrm{BMI}) \geq 95$ th centile and 50 overweight children and adolescents with 85 th $\leq$ BMI $<95$ th were screened for MS, prediabetes and NAFLD. Serum IL- 6 and TNF $\alpha$ were measured in all the participants and in 40 normal weight age-matched individuals (controls).

Results: IL-6 levels were increased in obese children and adolescents compared to the controls $(2.4 \pm 1.9$ vs $1.0 \pm 0.5 \mathrm{pg} / \mathrm{mL}, \mathrm{P}<$ $0.001)$ and to the overweight participants $(1.5 \pm 1.2 \mathrm{pg} / \mathrm{mL}, \mathrm{P}<$ 0.014). IL-6 was also elevated in overweight compared to normal weight youth $(\mathrm{P}=0.027)$ and in youth with MS compared to their counterparts without MS $(2.9 \pm 1.9 \mathrm{vs} 1.7 \pm 1.5 \mathrm{pg} / \mathrm{mL}, \mathrm{P}=0.013)$. $\mathrm{TNF} \alpha$ levels were comparable between obese and normal weight $(2.1 \pm 1.2$ vs $2.0 \pm 0.6 \mathrm{pg} / \mathrm{mL}$ respectively, $\mathrm{P}=0.805)$, overweight and normal weight $(2.0 \pm 1.0 \mathrm{pg} / \mathrm{mL}, \mathrm{P}=0.834)$, obese and overweight participants $(\mathrm{P}=0.997)$. Obese and overweight individuals with NAFLD had elevated levels of TNF $\alpha$ compared to their counterparts with normal liver $(2.7 \pm 1.1 \mathrm{vs} 1.0 \pm 1.0 \mathrm{pg} / \mathrm{mL}, \mathrm{P}=0.005)$.

Manuscript accepted for publication June 20, 2012

a'Department of Internal Medicine, "G.Gennimatas" General Hospital, Thessaloniki, Greece

${ }^{\mathrm{b}}$ Aristotle University of Thessaloniki, Third Department of Pediatrics, Hippokration General Hospital, Thessaloniki, Greece

${ }^{\mathrm{c}}$ Foundation of Biomedical Research, Academy of Athens, Athens,

Greece

${ }^{\mathrm{d}}$ Aristotle University of Thessaloniki, Medical School, Laboratory of Microbiology, Thessaloniki, Greece

${ }^{\text {e}}$ Corresponding author:Konstantinos Kitsios, 57 A. Papandreou str, Kalamaria, Thessaloniki, 55132, Greece. Email: kitsios_k@yahoo.gr

doi:10.4021/jem $111 \mathrm{w}$
Conclusions: Youth with excessive weight have elevated IL-6 levels, especially in the presence of MS. TNF $\alpha$ levels, although comparable between normal weight and excessive weight youth, are raised in overweight and obese individuals with NAFLD.

Keywords: Obesity; Metabolic syndrome; Prediabetes; Non Alcoholic Fatty Liver Disease; Inflammation

\section{Introduction}

Interleukin 6 (IL-6) and Tumor Necrosis Factor a (TNF $\alpha$ ) have been characterized in the recent years as indices of subclinical inflammation. Both are produced from the lipocytes and the macrophages that infiltrate the adipose tissue and have been associated, in adults' studies, with insulin resistance (IR), Metabolic Syndrome (MS), atherogenesis and non-alcoholic fatty liver disease (NAFLD) [1-6]. The presence of subclinical inflammation in children and adolescents has been reported in few studies with a limited number of participants [7].

The purpose of the study was to evaluate TNF $\alpha$ and IL-6 levels in obese and overweight children and adolescents and compare them to the levels of normal weight counterparts. Furthermore, TNF $\alpha$ and IL-6 levels of obese and overweight participants who also had MS, Prediabetes (Impaired Fasting Glucose (IFG) and/or Impaired Glucose Tolerance (IGT)) and NAFLD, were compared to the levels of obese and overweight children and adolescents who did not have any of the above metabolic disorders.

\section{Methods}

One hundred and forty four children and adolescents were included in the study, aged $6-17$ years old. According to the Body Mass Index (BMI) the participants were divided in 3 groups. Group A: 54 obese children and adolescents with BMI $\geq 95$ th centile for their age and sex. Group B: 50 Overweight children and adolescents with BMI between the 85th 
Table 1. Comparison of the Obese Children and Adolescents to the Control Group

\begin{tabular}{|c|c|c|c|}
\hline & Group A & Group C & $\mathbf{P}$ \\
\hline Patients (n) & 54 (28 female) & 40 (22 female) & \\
\hline Age (years) & $11.2 \pm 2.6$ & $10.8 \pm 2.8$ & 0.402 \\
\hline Weight (kg) & $71.0 \pm 18.8$ & $35.8 \pm 13.0$ & $<0.001$ \\
\hline BMI $\left(\mathrm{kg} / \mathrm{m}^{2}\right)$ & $30.7 \pm 3.7$ & $18.3 \pm 2.9$ & $<0.001$ \\
\hline $\mathrm{WC}(\mathrm{cm})$ & $104.0 \pm 12.3$ & $63.6 \pm 9.3$ & $<0.001$ \\
\hline Fasting Glucose (mg/dL) & $98.1 \pm 10.3$ & $84.0 \pm 7.1$ & $<0.001$ \\
\hline Fasting Insulin $(\mu \mathrm{U} / \mathrm{mL})$ & $25.0 \pm 14.4$ & $8.7 \pm 4.2$ & $<0.001$ \\
\hline HOMA-IR & $6.2 \pm 4.0$ & $1.8 \pm 0.9$ & $<0.001$ \\
\hline IL-6 (pg/mL) & $2.4 \pm 1.9$ & $1.0 \pm 0.5$ & $<0.001$ \\
\hline $\mathrm{TNF} \alpha(\mathrm{pg} / \mathrm{mL})$ & $2.1 \pm 1.2$ & $2.0 \pm 0.6$ & 0.805 \\
\hline
\end{tabular}

Table 2. Comparison of the Overweight Children and Adolescents to the Control Group

\begin{tabular}{llll}
\hline & Group B & Group C & P \\
\hline Patients $(\mathrm{n})$ & $50(30$ female $)$ & $40(22$ female $)$ & \\
Age (years) & $11.8 \pm 1.9$ & $10.8 \pm 2.8$ & 0.06 \\
Weight $(\mathrm{kg})$ & $60.1 \pm 10.5$ & $35.8 \pm 13.0$ & $<0.001$ \\
BMI $\left(\mathrm{kg} / \mathrm{m}^{2}\right)$ & $25.7 \pm 1.7$ & $18.3 \pm 2.9$ & $<0.001$ \\
WC $(\mathrm{cm})$ & $90.1 \pm 6.7$ & $63.6 \pm 9.3$ & $<0.001$ \\
Fasting Glucose $(\mathrm{mg} / \mathrm{dL})$ & $93.0 \pm 6.9$ & $84.0 \pm 7.1$ & $<0.001$ \\
Fasting Insulin $(\mu \mathrm{U} / \mathrm{mL})$ & $17.1 \pm 9.9$ & $8.7 \pm 4.2$ & $<0.001$ \\
HOMA-IR & $3.9 \pm 2.3$ & $1.8 \pm 0.9$ & 0.027 \\
IL-6 (pg/mL) & $1.5 \pm 1.2$ & $2.0 \pm 0.6$ & 0.997 \\
TNF $\alpha(\mathrm{pg} / \mathrm{mL})$ & $2.0 \pm 1.0$ & & \\
\hline
\end{tabular}


Table 3. Comparison Between Obese and Overweight Children and Adolescents

\begin{tabular}{llll}
\hline & Group A & Group B & P \\
\hline Patients (n) & $54(28$ female $)$ & $50(30$ female $)$ & \\
Age (years) & $11.2 \pm 2.6$ & $11.8 \pm 1.9$ & 0.207 \\
Weight $(\mathrm{kg})$ & $71.0 \pm 18.8$ & $60.1 \pm 10.5$ & 0.001 \\
BMI $\left(\mathrm{kg} / \mathrm{m}^{2}\right)$ & $30.7 \pm 3.7$ & $25.7 \pm 1.7$ & $<0.001$ \\
WC $(\mathrm{cm})$ & $104.0 \pm 12.3$ & $90.1 \pm 6.7$ & $<0.001$ \\
Fasting Glucose $(\mathrm{mg} / \mathrm{dL})$ & $98.1 \pm 10.3$ & $93.0 \pm 6.9$ & 0.004 \\
Fasting Insulin $(\mu \mathrm{U} / \mathrm{mL})$ & $25.0 \pm 14.4$ & $17.1 \pm 9.9$ & 0.001 \\
HOMA-IR & $6.2 \pm 4.0$ & $3.9 \pm 2.3$ & 0.001 \\
IL-6 (pg/mL) & $2.4 \pm 1.9$ & $1.5 \pm 1.2$ & 0.014 \\
TNF $\alpha(\mathrm{pg} / \mathrm{mL})$ & $2.1 \pm 1.2$ & $2.0 \pm 1.0$ & 0.834 \\
\hline
\end{tabular}

and 95th centile. Group C: 40 children and adolescents with $\mathrm{BMI}<85$ th centile (control group). Participants in group A and $\mathrm{B}$ were children and adolescents who consecutively attended the pediatric outpatient obesity clinic of the $3 \mathrm{rd} \mathrm{Pe}$ diatric Department of the University of Thessaloniki at the Hippokration General Hospital. All families were informed about the purpose of the study and written consent was obtained.

Weight was measured using high precision scale (accuracy $0.1 \mathrm{~kg}$ ) and height was measured with a Harpenter Stadiometer (accuracy of $1 \mathrm{~mm}$ ). BMI was calculated according to the formula weight $(\mathrm{kg}) /(\text { height }(\mathrm{cm}))^{2}$. Greek population centiles were used, as published from the 1rst Pediatric Department of the University of Athens. Waist circumference (WC) was measured with a flexible tape (accuracy of $1 \mathrm{~cm}$ ) at the middle of the distance between the last rib and the iliac crest.

A liver ultrasound scan to diagnose NAFLD and an oral glucose tolerance test (OGTT) were performed in groups $\mathrm{A}$ and $\mathrm{B}$. The participants were admitted to the unit in the morning, after a 12 hour fasting period. A cannula was inserted to the midcephalic and midcoronal vein. After the first sample (time 0$)$ an oral solution of D-glucose $(1.75 \mathrm{gr} /$ $\mathrm{kg}$, max dose 75 gr) was ingested during 2 - 3 minutes. All samples were transferred to the laboratory immediately for specification of glucose levels, which were calculated using the glucose exocinase enzymic method in the Architect 800c analyst (Abbott Laboratories, IL, USA, reference values: 75 - $100 \mathrm{mg} / \mathrm{dL}$ ). American Diabetes Association (ADA) and
International Diabetes Foundation (IDF) criteria were used to diagnose prediabetes (IFG: $100 \mathrm{mg} / \mathrm{dL} \leq$ fasting glucose $<126 \mathrm{mg} / \mathrm{dL}$ and/or IGT: $140 \mathrm{mg} / \mathrm{dL} \leq 2 \mathrm{hr}$ glucose $<200$ $\mathrm{mg} / \mathrm{dL})$.

MS was diagnosed according to the Cook criteria amended for the fasting glucose levels, where upper normal value was set to $100 \mathrm{mg} / \mathrm{dL}$ [8]. Waist circumference values were plotted to the USA Fernandez et al centiles for children and adolescents of European origin, since there are no published data applied to the Greek population [9].

All liver ultrasound scans were performed and assessed by the same sonographer, using a real time transducer 3.5 $\mathrm{MHz}$, according to pre-defined standards [10].

IR was calculated using the HOMA-IR (Homeostasis Model Assessment for Insulin Resistance) formula: (fasting glucose $(\mathrm{mmol} / \mathrm{L})) \times$ (fasting insulin $(\mu \mathrm{U} / \mathrm{mL})) / 22.5$. Insulin levels were calculated using the RIA method (reference values: 6 - $27 \mu \mathrm{U} / \mathrm{mL}$ ) whereas IL-6 and TNF $\alpha$ were measured using ELISA (Sandwich method, RnD sensitive IL-6 and $\mathrm{TNF} \alpha$ reagents).

\section{Statistical analysis}

Quantitative variables were summed up in averages and standard deviations. Student t-test was used in order to compare the averages in each group. The comparison of averages of all groups was done using the one-way ANOVA test. Tuckey post-hoc analysis was used for qualitative comparison. Nor- 
Table 4. Comparison Between Obese and Overweight Children and Adolescents With and Without MS

\begin{tabular}{llll}
\hline & MS & Without MS & P \\
\hline Patients (n) & 21 & 83 & \\
Age (years) & $11.3 \pm 2.5$ & $11.6 \pm 2.3$ & 0.578 \\
Weight $(\mathrm{kg})$ & $73.1 \pm 21.4$ & $64.2 \pm 14.2$ & 0.082 \\
BMI $\left(\mathrm{kg} / \mathrm{m}^{2}\right)$ & $31.4 \pm 4.7$ & $27.5 \pm 3.2$ & 0.002 \\
WC $(\mathrm{cm})$ & $102.0 \pm 12.5$ & $93.2 \pm 9.2$ & 0.005 \\
Fasting Glucose $(\mathrm{mg} / \mathrm{dL})$ & $100.0 \pm 9.7$ & $94.6 \pm 8.7$ & 0.015 \\
Fasting Insulin $(\mu \mathrm{U} / \mathrm{mL})$ & $29.9 \pm 17.3$ & $19.0 \pm 10.8$ & 0.011 \\
HOMA-IR & $7.6 \pm 5.0$ & $4.5 \pm 2.7$ & 0.012 \\
IL-6 (pg/mL) & $2.9 \pm 1.9$ & $1.7 \pm 1.5$ & 0.013 \\
TNF $\alpha(\mathrm{pg} / \mathrm{mL})$ & $2.2 \pm 1.0$ & $2.0 \pm 1.1$ & 0.641 \\
\hline
\end{tabular}

mality of variables was tested with the Shapiro-Wilk test and no deviation was noted. SPSS edition 16:0 was used for the statistical analysis and the level of significance was defined as lower than 0.05 in both directions.

\section{Results}

IL-6 levels were found significantly increased in obese children and adolescents compared to the normal weight $(2.4$ \pm 1.9 vs $1.0 \pm 0.5 \mathrm{pg} / \mathrm{mL}, \mathrm{P}<0.001)$ and to the overweight participants $(1.5 \pm 1.2 \mathrm{pg} / \mathrm{mL}, \mathrm{P}=0.014)$. IL-6 was also significantly elevated in overweight compared to normal weight youth $(\mathrm{P}=0.027)$. Obese and overweight children and adolescents with MS had significantly raised levels of IL-6 compared to their counterparts without the diagnosis of MS $(2.9 \pm 1.9$ vs $1.7 \pm 1.5 \mathrm{pg} / \mathrm{mL}, \mathrm{P}=0.013)$. IL-6 did not differentiate between obese and overweight participants with and without prediabetes $(1.9 \pm 1.5 \mathrm{vs} 2.0 \pm 1.8 \mathrm{pg} / \mathrm{mL}$, $\mathrm{P}=0.805)$, as well as with and without NAFLD $(2.6 \pm 2.2 \mathrm{vs}$ $1.7 \pm 1.4 \mathrm{pg} / \mathrm{mL}, \mathrm{P}=0.109$ ).

$\mathrm{TNF} \alpha$ levels were comparable between obese and normal weight $(2.1 \pm 1.2$ vs $2.0 \pm 0.6 \mathrm{pg} / \mathrm{mL}$, respectively, $\mathrm{P}=$ $0.805)$, between overweight and normal weight $(2.0 \pm 1.0 \mathrm{pg} /$ $\mathrm{mL}, \mathrm{P}=0.834)$ and between obese and overweight participants $(\mathrm{P}=0.997)$. Obese and overweight youth with NAFLD had significantly elevated levels of TNF $\alpha$ compared to their counterparts with normal liver $(2.7 \pm 1.1 \mathrm{pg} / \mathrm{mL}$ vs $1.0 \pm 1.0$ $\mathrm{pg} / \mathrm{mL}, \mathrm{P}=0.005)$. On the contrary, TNF $\alpha$ levels did not differentiate between obese and overweight participants with and without MS $(2.2 \pm 1.0 \mathrm{vs} 2.0 \pm 1.1 \mathrm{pg} / \mathrm{mL}$, respectively, $\mathrm{P}=0.641)$ as well as with and without prediabetes $(2.3 \pm 1.0$ vs $2.0 \pm 1.1 \mathrm{pg} / \mathrm{mL}$, respectively, $\mathrm{P}=0.205$ ).

MS was diagnosed in $17(31.5 \%)$ of the obese and 4 $(8 \%)$ of the overweight children and adolescents whereas prediabetes was found in $24(44.4 \%)$ and 12 (24\%) respectively. Among the obese participants with prediabetes 16 $(29.6 \%)$ had IFG, $3(5.6 \%)$ had IGT and $5(9.3 \%)$ had both IFG and IGT. Among the overweight children and adolescents with prediabetes $8(16 \%)$ had IFG, $3(6 \%)$ had IGT and only $1(2 \%)$ had both IFG and IGT. NAFLD was diagnosed in $24(44.4 \%)$ of the obese and $9(18 \%)$ of the overweight children and adolescents. The results of the between groups comparisons for all the parameters studied (median $\pm \mathrm{SD}$ ) are summarized in Table 1-3.

The results of the comparison between children and adolescents with and without MS, with and without prediabetes, with and without NAFLD are presented in Table 4-6 respectively.

\section{Discussion}

IL-6 is a cytokine which plays active role in the cellular and 
Table 5. Comparison Between Obese and Overweight Children and Adolescents With and Without Prediabetes

\begin{tabular}{llll}
\hline & Prediabetes & No Prediabetes & P \\
\hline Patients (n) & 35 & 69 & \\
Age (years) & $11.4 \pm 2.3$ & $11.6 \pm 2.4$ & 0.670 \\
Weight $(\mathrm{kg})$ & $68.2 \pm 16.5$ & $64.8 \pm 16.1$ & 0.322 \\
BMI $\left(\mathrm{kg} / \mathrm{m}^{2}\right)$ & $29.4 \pm 4.3$ & $27.8 \pm 3.6$ & 0.042 \\
WC $(\mathrm{cm})$ & $98.0 \pm 11.7$ & $93.4 \pm 9.6$ & 0.038 \\
Fasting Glucose $(\mathrm{mg} / \mathrm{dL})$ & $104.3 \pm 9.1$ & $91.3 \pm 5.3$ & $<0.001$ \\
Fasting Insulin $(\mu \mathrm{U} / \mathrm{mL})$ & $25.8 \pm 15.6$ & $19.0 \pm 11.0$ & 0.012 \\
HOMA-IR & $6.8 \pm 4.5$ & $4.3 \pm 2.5$ & 0.004 \\
IL-6 (pg/mL) & $1.9 \pm 1.5$ & $2.0 \pm 1.8$ & 0.805 \\
TNF $\alpha(\mathrm{pg} / \mathrm{mL})$ & $2.3 \pm 1.0$ & $2.0 \pm 1.1$ & 0.205 \\
\hline
\end{tabular}

humoral immune response to tissue damage. It is produced from several different cells including adipocytes and macrophages found in the adipose tissue. IL- 6 action is expressed by binding to its receptor and forming IL-6RB compound which is also known as glucoprotein 130 (GL 130) [6]. It enhances lipolysis and increases Free Fatty Acids (FFA) levels in the serum while inhibiting lipoprotein lipase [11]. Substantial amount of IL-6 is found in atherosclerotic layers of the endothelium [3-5]. In obese adults nearly $15-30 \%$ of the total IL- 6 is produced in the adipose tissue. Increased IL-6 levels show a positive relation to IR and cardiovascular risk which might even begin in childhood $[6,12,13]$.

In our study, obese children and adolescents had increased IL-6 levels compared to both overweight and normal weight counterparts. Significantly increased levels were also found in obese and overweight youth with MS compared to their counterparts without MS. In a recent cross-sectional study of 137 healthy prepubertal children, Galcheva et al reported higher levels of IL-6 in children with WC $>90$ th centile compared to those with WC $<90$ th [14]. IL-6 was also found elevated in overweight and obese adolescents compared to their lean counterparts in previous publications [15-19]. Stelzer et al reported, recently, increased IL-6 levels in obese youth with MS compared to those without the syndrome [16]. On the contrary, Galcheva et al failed to show any significant association of IL-6 with parameters of the MS other than with low HDL- cholesterol [14].
IL-6, in our study, did not differ between overweight and obese youth with and without prediabetes. In consistence with our findings, Metzig et al, studying postprandial endothelial function, inflammation and oxidative stress in 34 obese children and adolescents, reported no difference in the levels of IL-6 at $1 \mathrm{~h}$ and $2 \mathrm{~h}$ after glucose ingestion [20]. On the contrary, Yeste at al found significantly elevated levels of IL-6 in 14 obese children with prediabetes compared to those with normal glucose metabolism [19]. It is evident that further studies are needed in order to fully investigate the potential correlation of IL- 6 with impaired glucose metabolism in youth.

We found no difference in the levels of IL-6 between overweight and obese children and adolescents with and without NAFLD. In two recent studies in obese youth, hepatocellular lipid content assessed with magnetic resonance imaging was positively associated with the levels of IL-6 [21-22]. Similarly Alisi et al reported elevated IL-6 in obese children with biopsy proven NAFLD compared to normal weight controls [23]. Diagnostic limitations of ultrasonography in detecting NAFLD could account for the discrepancy in our results.

TNF $\alpha$ is mainly produced by macrophages and lymphocytes, under the effect of other cytokines produced in the adipose tissue, while small amounts are also produced directly from adipocytes [13]. TNF $\alpha$ enhances lipolysis and increases FFA levels in the plasma. It activates phosphorylases 
Table 6. Comparison Between Obese and Overweight Children and Adolescents With and Without NAFLD

\begin{tabular}{llll}
\hline & NAFLD & No NAFLD & P \\
\hline Patients (n) & 33 & 71 & \\
Age (years) & $11.0 \pm 2.3$ & $11.7 \pm 2.3$ & 0.158 \\
Weight $(\mathrm{kg})$ & $67.1 \pm 19.4$ & $65.5 \pm 14.6$ & 0.643 \\
BMI $\left(\mathrm{kg} / \mathrm{m}^{2}\right)$ & $29.5 \pm 4.8$ & $27.8 \pm 3.3$ & 0.068 \\
WC $(\mathrm{cm})$ & $97.4 \pm 12.4$ & $93.9 \pm 9.4$ & 0.154 \\
Fasting Glucose $(\mathrm{mg} / \mathrm{dL})$ & $94.7 \pm 10.5$ & $96.1 \pm 8.5$ & 0.460 \\
Fasting Insulin $(\mu \mathrm{U} / \mathrm{mL})$ & $24.4 \pm 13.9$ & $19.7 \pm 12.4$ & 0.089 \\
HOMA-IR & $5.8 \pm 3.7$ & $4.8 \pm 3.4$ & 0.136 \\
IL-6 (pg/mL) & $2.6 \pm 2.2$ & $1.7 \pm 1.4$ & 0.109 \\
TNFa $(\mathrm{pg} / \mathrm{mL})$ & $2.7 \pm 1.1$ & $1.9 \pm 1.0$ & 0.005 \\
\hline
\end{tabular}

in adipocytes which phosphorylate aminoacids in specific areas of the Insulin Receptor Substrate -1 (IRS-1) resulting in the inhibition of receptor signaling to the glucose transportation system. Furthermore, it inhibits lipoproteinic lipase and adipocyte differentiation while it is possible to enhance adipocyte apoptosis [11]. Obese individuals have been found with increased TNF $\alpha$ levels in several adults' publications. In adults, there is correlation between elevated TNF $\alpha$ levels and Insulin Resistance, Diabetes, endothelial dysregulation and raised C-Reactive Protein (CRP) and IL-6 levels [3].

There are limited and conflicting published data regarding the role of TNF in childhood and adolescence obesity [7]. In our study, we found no difference in the levels of TNF $\alpha$ between obese, overweight and normal weight children and adolescents. Similarly, Galcheva et al reported no difference in TNF $\alpha$ levels in abdominally obese prepubertal children compared to those with normal weight [14]. SteeneJohannessen et al did not find correlation of TNF $\alpha$ with WC or other cardiovascular risk factors in 2.300 children aged 9 - 15 years old [24]. On the contrary, others have reported elevated TNF $\alpha$ in obese versus normal weight children and adolescents [15, 18, 25-27]. It is possible that different gene polymorphisms encoding TNF $\alpha$ could account for TNF $\alpha$ effect in early atheromatosis, independently of the body weight [28].

In consistence with our findings, Alikasifoglu et al reported no difference in TNF $\alpha$ levels among obese children and adolescents with and without MS, as well as with and without prediabetes [27]. Given the lack of data, more studies are needed to elucidate the relationship of $\mathrm{TNF} \alpha$ with these metabolic disorders in youth.

In recent years TNF $\alpha$ and its relation to NAFLD has been extensively investigated in adults. The enhancing effect on lipolysis results in increased FFA production which accumulate in the liver and activate liver factor kappa $\mathrm{B}(\mathrm{NF} \kappa \mathrm{B})$ which then result in increased production of cytokines(TNF $\alpha$, IL-6, CRP) and oxidating factors from hepatocytes and Kupffer cells. Most of these cytokines are also produced by visceral fat and further induce NAFLD and NASH by several mechanisms involving hepatocyte apoptosis and liver fibrosis [29].

The potential pathogenetic role of TNF $\alpha$ in NAFLD is also supported in our study where we found that obese and overweight children and adolescents with NAFLD had significantly raised TNF $\alpha$ levels compared to their counterparts without NAFLD. Alisi et al also reported elevated TNF $\alpha$ in obese children with biopsy proven NAFLD compared to normal weight controls [23]. Fasting serum levels of TNF $\alpha$ and its soluble receptors have been shown to correlate with ultrasonographic grade of liver steatosis in obese children [30]. It has recently been published that TNF $\alpha$ levels show positive correlation with the degree of histological damage of fatty liver. Therefore, raised TNF $\alpha$ levels could be a marker of the evolution of steatohepatitis to more severe inflammatory 
status and gradually fibrosis [31].

In conclusion, obese and overweight children and adolescents in our study had significantly raised IL-6 levels compared to normal weight children, reinforcing the evidence that subclinical inflammation is already present in childhood obesity. The degree of inflammation seems to be more potent when MS is also present. Therefore, overweight and obese youth with MS should be treated more intensively since they may run additional cardiovascular risk in the future. Obese and overweight children with NAFLD had significantly elevated TNF $\alpha$ levels compared to their counterparts with normal liver. The role of TNF $\alpha$ in the pathogenesis and the evolution of fatty liver disease in childhood and adolescence remain to be elucidated by further research.

\section{Authors' Contribution}

Dr Kitsios, Dr Papadopoulou, Dr Kosta, Dr Papagianni, Dr Tsiroukidou are the main researchers. Dr Chatzidimitriou, Dr Chatzopoulou and Dr Malisiovas performed the laboratory measurements and Dr Kadoglou the statistics.

\section{Grant Support and Conflict of Interest}

The authors did not receive any funding and disclose no conflict of interest.

\section{Abbreviations}

BMI: Body Mass Index; CRP: C-Reactive Protein; FFA: Free Fatty Acids; HOMA: Homeostasis Model Assessment; IFG: Impaired Fasting Glucose; IGT: Impaired Glucose Tolerance; IL-6: Interleukin-6; IR: Insulin Resistance; MS: Metabolic Syndrome; NAFLD: Non Alcoholic Fatty Liver Disease; TNF $\alpha$ : Tumor Necrosis Factor $\alpha$; WC: Waist Circumferance.

\section{References}

1. Arner P. Insulin resistance in type 2 diabetes -- role of the adipokines. Curr Mol Med. 2005;5(3):333-339.

2. Langenberg $\mathrm{C}$, Bergstrom J, Scheidt-Nave C, Pfeilschifter J, Barrett-Connor E. Cardiovascular death and the metabolic syndrome: role of adiposity-signaling hormones and inflammatory markers. Diabetes Care. 2006;29(6):1363-1369.

3. Devaraj S, Rosenson RS, Jialal I. Metabolic syndrome: an appraisal of the pro-inflammatory and procoagulant status. Endocrinol Metab Clin North Am. 2004;33(2):431-453, table of contents.
4. Bastard JP, Maachi M, Van Nhieu JT, Jardel C, Bruckert E, Grimaldi A, Robert JJ, et al. Adipose tissue IL-6 content correlates with resistance to insulin activation of glucose uptake both in vivo and in vitro. J Clin Endocrinol Metab. 2002;87(5):2084-2089.

5. Anfossi G, Russo I, Doronzo G, Pomero A, Trovati M. Adipocytokines in atherothrombosis: focus on platelets and vascular smooth muscle cells. Mediators Inflamm. 2010;2010:174341.

6. Fisman EZ, Tenenbaum A. The ubiquitous interleukin-6: a time for reappraisal. Cardiovasc Diabetol. 2010;9:62.

7. Tam CS, Clement K, Baur LA, Tordjman J. Obesity and low-grade inflammation: a paediatric perspective. Obes Rev. 2010;11(2):118-126.

8. Cook S, Weitzman M, Auinger P, Nguyen M, Dietz WH. Prevalence of a metabolic syndrome phenotype in adolescents: findings from the third National Health and Nutrition Examination Survey, 1988-1994. Arch Pediatr Adolesc Med. 2003;157(8):821-827.

9. Fernandez JR, Redden DT, Pietrobelli A, Allison DB. Waist circumference percentiles in nationally representative samples of African-American, European-American, and Mexican-American children and adolescents. J Pediatr. 2004;145(4):439-444.

10. Palmentieri B, de Sio I, La Mura V, Masarone M, Vecchione $\mathrm{R}$, Bruno $\mathrm{S}$, Torella $\mathrm{R}$, et al. The role of bright liver echo pattern on ultrasound B-mode examination in the diagnosis of liver steatosis. Dig Liver Dis. 2006;38(7):485-489.

11. Mattison R, Jensen M. The adipocyte as an endocrine cell. Curr Opin Endocrinol Diabetes 2003;10:317-321

12. Bastard JP, Maachi M, Lagathu C, Kim MJ, Caron M, Vidal H, Capeau J, et al. Recent advances in the relationship between obesity, inflammation, and insulin resistance. Eur Cytokine Netw. 2006;17(1):4-12.

13. Galic S, Oakhill JS, Steinberg GR. Adipose tissue as an endocrine organ. Mol Cell Endocrinol. 2010;316(2):129139.

14. Galcheva SV, Iotova VM, Yotov YT, Bernasconi S, Street ME. Circulating proinflammatory peptides related to abdominal adiposity and cardiometabolic risk factors in healthy prepubertal children. Eur J Endocrinol. 2011;164(4):553-558.

15. Gobel RJ, Jensen SM, Frokiaer H, Molgaard C, Michaelsen KF. Obesity, inflammation and metabolic syndrome in Danish adolescents. Acta Paediatr. 2012;101(2):192-200.

16. Stelzer I, Zelzer S, Raggam RB, Pruller F, TruschnigWilders M, Meinitzer A, Schnedl WJ, et al. Link between leptin and interleukin- 6 levels in the initial phase of obesity related inflammation. Transl Res. 2012;159(2):118124.

17. Mauras N, Delgiorno C, Kollman C, Bird K, Morgan M, Sweeten S, Balagopal P, et al. Obesity without es- 
tablished comorbidities of the metabolic syndrome is associated with a proinflammatory and prothrombotic state, even before the onset of puberty in children. J Clin Endocrinol Metab. 2010;95(3):1060-1068.

18. Halle M, Korsten-Reck U, Wolfarth B, Berg A. Lowgrade systemic inflammation in overweight children: impact of physical fitness. Exerc Immunol Rev. 2004;10:66-74.

19. Yeste D, Vendrell J, Tomasini R, Broch M, Gussinye M, Megia A, Carrascosa A. Interleukin-6 in obese children and adolescents with and without glucose intolerance. Diabetes Care. 2007;30(7):1892-1894.

20. Metzig AM, Schwarzenberg SJ, Fox CK, Deering MM, Nathan BM, Kelly AS. Postprandial endothelial function, inflammation, and oxidative stress in obese children and adolescents. Obesity (Silver Spring). 2011;19(6):12791283.

21. Weghuber D, Roden M, Franz C, Chmelik M, Torabia S, Nowotny P, Gruber S, et al. Vascular function in obese children with non-alcoholic fatty liver disease. Int J Pediatr Obes. 2011;6(2):120-127.

22. Cali AM, De Oliveira AM, Kim H, Chen S, ReyesMugica M, Escalera S, Dziura J, et al. Glucose dysregulation and hepatic steatosis in obese adolescents: is there a link? Hepatology. 2009;49(6):1896-1903.

23. Alisi A, Manco M, Devito R, Piemonte F, Nobili V. Endotoxin and plasminogen activator inhibitor-1 serum levels associated with nonalcoholic steatohepatitis in children. J Pediatr Gastroenterol Nutr. 2010;50(6):645649.

24. Steene-Johannessen J, Kolle E, Reseland JE, Anderssen SA, Andersen LB. Waist circumference is related to low-grade inflammation in youth. Int $\mathrm{J}$ Pediatr Obes.
2010;5(4):313-319.

25. Shin JY, Kim SY, Jeung MJ, Eun SH, Woo CW, Yoon SY, Lee KH. Serum adiponectin, C-reactive protein and TNF-alpha levels in obese Korean children. J Pediatr Endocrinol Metab. 2008;21(1):23-29.

26. Caballero AE, Bousquet-Santos K, Robles-Osorio L, Montagnani V, Soodini G, Porramatikul S, Hamdy O, et al. Overweight Latino children and adolescents have marked endothelial dysfunction and subclinical vascular inflammation in association with excess body fat and insulin resistance. Diabetes Care. 2008;31(3):576-582.

27. Alikasifoglu A, Gonc N, Ozon ZA, Sen Y, Kandemir $\mathrm{N}$. The relationship between serum adiponectin, tumor necrosis factor-alpha, leptin levels and insulin sensitivity in childhood and adolescent obesity: adiponectin is a marker of metabolic syndrome. J Clin Res Pediatr Endocrinol. 2009;1(5):233-239.

28. Mendoza-Carrera F, Ramirez-Lopez G, Ayala-Martinez NA, Garcia-Zapien AG, Flores-Martinez SE, SanchezCorona J. Influence of CRP, IL6, and TNFA gene polymorphisms on circulating levels of $\mathrm{C}$-reactive protein in Mexican adolescents. Arch Med Res. 2010;41(6):472477.

29. Marra F, Bertolani C. Adipokines in liver diseases. Hepatology. 2009;50(3):957-969.

30. Lebensztejn DM, Kowalczuk D, Tarasow E, Skiba E, Kaczmarski M. Tumor necrosis factor alpha and its soluble receptors in obese children with NAFLD. Adv Med Sci. 2010;55(1):74-79.

31. Manco M, Marcellini M, Giannone G, Nobili V. Correlation of serum TNF-alpha levels and histologic liver injury scores in pediatric nonalcoholic fatty liver disease. Am J Clin Pathol. 2007;127(6):954-960. 